Anna Szylar

Instytut Pedagogiki

PWSZ im. prof. S. Tarnowskiego

$w$ Tarnobrzegu

\title{
Nasze naymilsze siestrzyczki... czyli habitki w klasztorze Wizytek Warszawskich w XVII wieku ${ }^{1}$
}

Siostry Zakonu Nawiedzenia Najświętszej Maryi Panny nazywane w Polsce wizytkami sprowadzone zostały do Warszawy przez królową Ludwikę Marię w 1654 r. Królowa zakupiła place na Krakowskim Przedmieściu, budując tam drewniany kościół i klasztor oraz zabezpieczyła je materialnie przez uposażenie dobrami kamieńczykowskimi.

Wspólnota założona została w 1610 r. przez biskupa genewskiego Franciszka Salezego w celu prowadzenia działalności opiekuńczej i charytatywnej, ale w 1618 r. papież przekształcił ją w zakon. Po śmierci założyciela w 1622 r., zgodnie z jego intencją, opiekę nad zakonem przejął ks. Wincenty a Paulo. Organizacja zakonu była odmienna od tradycyjnych konwentów żeńskich o surowej regule, wizytki należały do zakonów kontemplacyjnych, tzw. nowego typu, zajmujących się pracą na rzecz społeczeństwa.

Królowa, sprowadzając wizytki do Polski postawiła przed nimi zadania o charakterze edukacyjnym i dobroczynnym. Zgodnie z ostatecznymi dyrektywami królowej z września 1654 r. siostry zobowiązane były prowadzić szkołę klasztorną dla dziewcząt. Ponadto po wybudowaniu murowanego kościoła i klasztoru miały utrzymywać na pensji oprócz uczennic płatnych, również 12 ubogich dziewczynek na koszt klasztoru oraz otworzyć szkołę dla dziewcząt dochodzących z miasta. Aby zrealizować powyższe zalecenia po-

${ }^{1}$ Artykuł powstał na bazie poszukiwań źródeł archiwalnych do dziejów szkolnictwa klasztornego żeńskiego. Wykorzystano znajdujące się w Archiwum Sióstr Wizytek Warszawskich (dalej: AWiWa): księgę rachunkową z lat 1654-1714, kroniki klasztorne sporządzone w oparciu o źródła klasztorne przez s. Marię Kazimierę Fertner w pierwszej połowie XX w., regułę zakonną, tzw. małą regułę spisaną dla habitek i ich mistrzyń, księgę zawierającą spis dokumentów klasztornych oraz żywot s. Katarzyny Krystyny Branickiej (dokładne dane bibliograficzne znajdują się poniżej w przypisach).

Składam serdeczne podziękowania Matce Przełożonej Zakonu Nawiedzenia Najświętszej Marii Panny Klasztoru Sióstr Wizytek w Warszawie za udostępnienie materiałów źródłowych, a szczególne wyrazy wdzięczności kieruję do Siostry Archiwistki Marii Emanuelii za okazaną życzliwość i wszelką pomoc w trakcie prowadzonych poszukiwań. 
winny zatrudnić i opłacić 6 nauczycielek. Jednak jak wynika z ksiąg rachunkowych klasztor nie ponosił tego typu wydatków².

Ponieważ wizytki należały do zakonów klauzurowych, a nauczycielkami były zakonnice, szkoła dla dziewcząt musiała się więc znajdować wewnątrz klauzury, jednak w oddzielonej od zajmowanej przez siostry części klasztoru. Naukę pobierały uczennice zamieszkujące na pensji klasztornej, ale do szkoły przychodziły też ubogie dziewczynki z miasta, potwierdzają to opłaty pensjonarek i darowizny na rzecz klasztoru ze strony tzw. dochodzących eksternistek ${ }^{3}$.

Program nauczania obejmował czytanie oraz pisanie po francusku i po polsku, edukację religijną, śpiew, muzykę i prace ręczne. Dziewczęta nosiły ciemne, skromne sukienki, wykonywały drobne prace fizyczne, przygotowywano je do życia zgodnie z ich pochodzeniem społecznym i pozycją, jaką miały zająć w społeczeństwie, starano się też rozwijać ich intelekt oraz wychowywać w duchu katolicyzmu ${ }^{4}$.

Oprócz pensjonarek w oddzielonej od szkoły części klasztoru zamieszkiwały nowicjuszki przygotowujące się do złożenia ślubów zakonnych. Zamieszkiwały w wyznaczonych dla nich pomieszczeniach, nie były izolowane od profesek, chodziły w habitach i wraz z zakonnicami tworzyły chór zakonny ${ }^{5}$. Zgodnie z prawem kanonicznym od XVI w. warunkiem przyjęcia do nowicjatu było ukończenie 15 roku życia, wyjątkowo dopuszczano dziewczęta 12-letnie, natomiast śluby profesji uznawano za nieważne, gdy były złożone przed ukończeniem 16 lat życia. Konieczna była też dobrowolna decyzja kandydatki,

2 J. L. Jastrzębski, Polskie wizytki czyli historia fundacyi pierwszego klasztoru zakonnic Nawiedzenia Panny Maryi w Warszawie, Rzym 1849, s. 99; F. Sobieszczański, Kościół i klasztor PP. Wizytek w Warszawie, w: „Pamiętnik Religijno-Moralny”, 31(1856), seria 1, s. 270-271; E. Janicka-Olczakowa, Zakony żeńskie w Polsce, w: J. Kłoczowski (red.), Kościół w Polsce, t. 2, Wiek XVI-XVIII, Kraków 1970, s. 758-759; K. Targosz, Uczony dwór Ludwiki Marii Gonzagi (1646-1667). Z dziejów polsko-francuskich stosunków naukowych, Warszawa 1975, s. 375-377; B. Fabiani, Warszawski dwór Ludwiki Marii, Warszawa 1976, s. 69-73; B. Fabiani, Warszawska pensja panien wizytek w latach 1655-1680, w: Warszawa XVI- XVII wieku, z. 2, Instytut Polskiej Akademii Nauk, Warszawa 1977, s. 174-176; S. Litak, Z problemów edukacji dziewcząt w Polsce w XVII-XVIII wieku, „Kwartalnik Pedagogiczny” 1995 3(157), s. 47-48; S. Litak, Francuski nurt w wychowaniu i szkolnictwie w Polsce w XVII i XVIIII wieku, w: Ecclesia Posnaniensis Opuscula Mariano Banaszak Septuagenario Dedicata, Uniwersytet im. Adama Mickiewicza Wydział Teologiczny, Poznań 1998, s. 145-146; A. Szylar, Działalność oświatowa benedyktynek sandomierskich w latach 1616-1865, Lublin 2002, s. 43, 46-47.

${ }^{3}$ B. Fabiani, Warszawska pensja..., s. 181; AWiWa, rps Livre auquel est escrit les rooles des derniers reçeur et emploier en ce monastére de la visitation ste marie de pologne comancé en l'année 1654, (Księga rachunkowa z lat 1654-1714), sygn. D 3. Zapisy darowizn na rzecz klasztoru to przede wszystkim drobne artykuły żywnościowe i tak w 1670 r. podarowały na Wielkanoc 3 chleby i 2 garnce wina, następnie 8 kapłonów, 3 kurczęta i półmisek galarety, trochę jabłek, jajek i 4 baranie futerka, innym razem w 1673 r. poziomki, 6 kurcząt i 3 gęsi, 2 kaczki, 8 jaj i kamień tłuszczu, a jeszcze w innym czasie 3 gęsi, 3 ryby, 2 króliki i 2 gołąbki. Zapisy tego typu darowizn pochodzą z lat 1670-1671. Zob. też: AWiWa, rps Kronika klasztoru naszego warszawskiego 1668-1682, t. 3, sygn. B 8, s. 54, 59, 66, 74, 129, 132, 134.

${ }^{4}$ AWiWa, rps Kutumiarz i Direktorium Sióstr zakonnic Nawiedzenia Najświętszej Panny, z francuskiego na polski język przettumaczony, przez siostry tegoż zakonu i do druku podany w Warszawie 2 czerwca 1862 (według oryginału z 1682 r.), sygn. A 14; B. Fabiani, Warszawska pensja, s. 178-180; K. Targosz, Sawantki w Polsce w XVII w. Aspiracje intelektualne kobiet ze środowisk dworskich, Warszawa 1997, s. 181-182. Zob. też D. Żołądź-Strzelczyk, Dzieje edukacji kobiet w Polsce przedrozbiorowej w: Studia z dziejów edukacji kobiet na ziemiach polskich, red. D. Żołądź-Strzelczyk, W. Jamrożek, Poznań 2001, s. 67-68.

${ }_{5}^{5}$ M. Borkowska, Życie codzienne polskich klasztorów żeńskich w XVII i XVIII wieku, Warszawa 1996, s. 34 . 
którą przed złożeniem ślubów delegat biskupi przepytywał o intencję. Chodziło o zbadanie prawdziwości wypowiedzi kandydatki i eliminację narzucania córkom woli rodziców, którzy z różnych powodów przeznaczali je do stanu zakonnego. Istniał zakaz przyjmowania do nowicjatu dzieci przyniewolonych, a intencja rodziców ofiarowania dziecka Bogu była nieważna i tylko wola kandydatki poparta zgodą rodziców mogła spowodować wstąpienie jej do zakonu6.

Wśród mieszkanek klasztoru były także kilkuletnie dziewczynki, które od najmłodszych lat przygotowywały się do wstąpienia do zakonu. Chodziły ubrane w małe habity, szyte na wzór stroju zakonnic, dlatego też nazywano je habitkami. I właśnie ta grupa dziewcząt jest tematem niniejszych rozważań. W żadnym innym zakonie nie napotkałam w źródłach archiwalnych wydzieloną w taki sposób grupę dzieci, stanowiących specyficzną społeczność zakonną. Nie oznacza to, że w innych klasztorach nie zamieszkiwały małe dziewczynki, które niekiedy także ubierano w habity, zdarzało się to jednak sporadycznie i albo przebywały w szkole klasztornej, albo wychowywały je indywidualnie zakonnice. Ten drugi zwyczaj był zresztą sprzeczny z potrydenckimi regulacjami prawnymi w sprawach organizacji życia zakonnego w żeńskich zakonach klauzurowych.

W szkole u wizytek warszawskich, a więc w części budynku klasztornego oddzielonej od cel zakonnic spotykamy również małe, kilkuletnie dziewczynki, podobnie jak na pensji przykładowo u norbertanek imbramowickich, gdzie przebywała 3-letnia wojewodzianka poznańska, Ewa Ponińska. Po upływie roku dziewczynkę odebrali rodzice, dziękując za piękna edukacya, gdyż nad lata swoje sposobność wielka miała do nauczenia się nauki chrześcijańskiej, pacierza i innych modlitewek $i$ wszystkiego dobrego ${ }^{7}$.

$\mathrm{Z}$ kolei u bernardynek krakowskich była na wychowaniu pod koniec XVII w. panienka świecka Magdalena Starowiejska, która rodzice dali na ćwiczenie do klasztoru naszego $w$ siedmiu leciach, dziewczynka robiła znaczne postępy w nauce, odprawiała rekolekcje, medytacje dyscypliny niedziecinne $i$ umartwienia jeszcze niedospana, ale największą radość sprawiało jej ubierać się po zakonnemu ${ }^{8}$. Niestety, pomimo deklaracji pozostania w zakonie nie dane jej było wstąpić do nowicjatu, po trzech latach od przybycia zmarła9 Przykład powyższy potwierdza fakt przyjmowania na wychowanie kilkuletnich dziewczynek. Nie wiemy jednak, kiedy zrodziło się u niej zamiłowanie do noszenia habitu, czy było to jeszcze w domu rodzinnym, czy w trakcie pobytu wśród zakonnic. Na podobne przykłady można natrafić na łamach różnych źródeł klasztornych.

Habitki u wizytek były nazywane siostrzyczkami lub małymi siostrzyczkami, a specjalne instrukcje regulowały zasady ich przyjmowania, pobytu i wychowania, czego także

\footnotetext{
${ }^{6}$ M. Borkowska, Życie codzienne..., s. 15. Jako przykład można powołać się na wydaną w 1605 r. przez kongregację chełmińską Regułę św. Benedykta, rozdział 59 dotyczył dzieci ofiarowanych Bogu, a komentarz do niej jednoznacznie określał, że intencja rodziców ofiarowania dziecka Bogu jest nieważna i do nowicjatu nie można przyjmować takich kandydatek.

${ }^{7}$ ANI, rps Historia domowa klasztoru imbramowskiego zakonu premonstrateńskiego odemnie Zofii Grothówny ksieni, ręka własna pisana. I sobie dla pamięci i sukcesorkom dla informacyi dalszej zostawiona, a w roku 1703 zaczęta, sygn. A 27, s. 501-502.

${ }^{8}$ Archiwum Bernardynek w Krakowie, rps Regestr wielebnych panien zakonnic trzeci(ej) reguly Franciszka ś. w klasztorze pod tytułem Jozepha w mieście stołecznym Krakowskim, sygn. 129, s. 100.

9 Ibidem, s. 101.
} 
nie spotyka się w innych konwentach. Powinny mieć dobry charakter, chęć pozostania w zakonie, być stałego rozumu, dowcipne, prędkie do pojęcia, jak wedtug ducha jako $i$ wedtug ciała ${ }^{10}$. Ponieważ były to dziewczynki w różnym wieku, począwszy od kilku do kilkunastoletnich, również i stawiane im wymagania były zróżnicowane. O właściwą opiekę, wychowanie i przygotowanie do życia w zakonie troszczyła się wyznaczona przez przełożoną mistrzyni. W dniu przybycia do klasztoru mistrzyni ubierała dziewczynkę w mały habit zakonny, zaprowadzała do przełożonej, która im welum małe włoży na gło$w e^{11}$. Czynności te odbywały się bez żadnych dodatkowych ceremonii. Sposób postępowania z habitkami, rozkład dnia i zakres ich obowiązków określała Reguła dla naszych najmilszych siestrzyczek zawarta w wydrukowanym w 1682 r., przetłumaczonym z języka francuskiego Kutumiarzu i Direktorium Sióstr zakonnic Nawiedzenia Nayświętszey Pan$n y^{12}$.

Sygnał dzwonka wzywającego zakonnice na prymę, czyli pierwsze w danym dniu modlitwy, był dla habitek znakiem końca nocnego wypoczynku, w zimie było to o godzinie 6.30, a latem pobudka następowała pół godziny wcześniej. Po przebudzeniu dziewczynki powinny szybko wstać i uklęknąć do porannych pacierzy składających się z prośby o błogosławieństwo Boże na nowy dzień oraz modlitwy do Najświętszej Maryi i Aniołów Stróżów. Następnie pół godziny przeznaczano na ubranie się i poranną toaletę, w jej zakres wchodziło mycie rąk i czesanie, następnie dziewczynki udawały się do chóru zakonnego na adorację Najświętszego Sakramentu i modlitwę, co trwało około kwadransa.

Zgodnie z obowiązującą instrukcją po porannych modlitwach dzieci pójdą do swej mistrzyni uczyć się rzeczy potrzebnych ${ }^{13}$, zajęcia nie trwały długo, po ich zakończeniu spożywano śniadanie. Przez cały czas opiekę nad habitkami sprawowała mistrzyni, były one zobowiązane słuchać poleceń i wypełniać je wszystkie bez marudzenia i opieszałości. Ponieważ dziewczynki rozwijały się i potrzebowały odpowiedniej ilości pożywnego pokarmu, przygotowywano dla nich cztery posiłki dziennie. Spożywały śniadanie, obiad, podwieczorek i wieczerzę, zakonnice zaś konsumowały tylko obiad i kolację. W refektarzu obok stołów dla zakonnic ustawiony był mały stolik dla dziewczynek, dwa posiłki jadły wspólnie z wizytkami, a pozostałe dwa w godzinach wyznaczonych przez przełożoną. Nie znamy dokładnego planu posiłków, ale mógł być on zbliżony do rozkładu dnia pensjonarek, które śniadanie spożywały o godzinie 8.00 latem i 8.30 zimą, obiad o 10-10.30, podwieczorek o 14.30 i kolację około godziny $18.00^{14}$.

Na podkreślenie zasługuje dbałość sióstr o właściwe odżywianie dzieci i świadomość konieczności dostarczenia odpowiedniej ilości pełnowartościowego jedzenia. Świadczą o tym wydatki na artykuły żywnościowe, szczególnie w okresie Wielkiego Postu, gdy zakonnice obowiązywała ścisła dieta, a dla habitek i pensjonarek kupowano pożywne,

\footnotetext{
${ }^{10}$ AWiWa, rps Zebranie tego wszystkiego co się znayduje w Pismach Naszych, należacych do Przełożoney y Jey Rządu. Wypisane przez siostry nasze de Caen Zakonu Naw. Nayś. Panny, sygn. A 19, brak paginacji.

11 Ibidem.

12 AWiWa, sygn. A 14, s. 397-400.

13 Ibidem, s. 398.

14 Ibidem, s. 397-400.
} 
treściwe artykuły żywnościowe i nie żałowano na nie pieniędzy. Wśród nabywanych produktów były kurczęta, raki, mięso, ryby, jaja, mleko jak wpisywano w księgach rozchodów z przeznaczeniem dla dziewcząt, bo wszyscy [dorośli - A.Sz.] oddawali się surowemu umartwieniu i wydatki na żywność były minimalne ${ }^{15}$.

Aby zbytnio nie przeciążać młodych organizmów dzieci zajęciami, w plan dnia wpisana była po śniadaniu i po obiedzie rekreacja, tę ostatnią odbywały wraz z zakonnicami. Wspólny odpoczynek z siostrami umożliwiał dokładniejsze poznanie zwyczajów i zasad panujących we wspólnocie, przysłuchiwanie się nabożnym rozmowom i stanowił jeden z elementów kształtowania duchowości dziewczynek.

Czas po rekreacji poświęcony był na naukę, a jej zakres zależał od wieku habitek i ich możliwości intelektualnych. Jeśli były to starsze dziewczynki, mogły za zgodą mistrzyni iść do nowicjatu, ile będzie potrzeba dla stuchania wykładu katechizmu albo Reguty i Direktorium, gdy zaś młodsze to pójdą z swa [mistrzynią - A.Sz.] uczyć się tego, co im roz$k a \dot{z} e^{16}$. Po zjedzeniu podwieczorku miały czas na spacery, przechadzki i zabawy ruchowe. Zaplanowana w taki sposób pozostała część dnia potwierdza wiedzę zakonnic na temat znajomości potrzeb rozwojowych dziecka i nawet, jeśli zabawy przerywano nabożeństwami popołudniowymi czy kolacją, to potem pozwalano dziewczynkom na powrót do nich.

Habitki uczestniczyły także codziennie we Mszy św. i zobowiązane były odmawiać $\mathrm{w}$ trakcie jej trwania modlitwy swoim językiem [...] przyrodzonym, jako ich naucza, bywały na nieszporach, komplecie, litaniach, odmawiały koronki, uczono je modlitw indywidualnych i wspólnotowych ${ }^{17}$. Każdy dzień kończyły rachunkiem sumienia, po nim dopiero udawały się na nocny odpoczynek. Uczestnictwo w nabożeństwach i modlitwach wspólnotowych stanowiło ważny element wychowania zakonnego, umożliwiało naukę tekstów i śpiewu liturgicznego, pozwalało przez obserwację życia zakonnic, powoli wdrażać habitki do przyszłych obowiązków, uczyć cierpliwości i rozumienia znaczenia modlitwy. Oczywiście dla dziewczynek, szczególnie tych mniejszych, było to dość trudne. Niełatwo sobie wyobrazić, aby małe dziecko było w stanie przez dłuższy czas skoncentrować się na jednej czynności, stać lub siedzieć spokojnie, prawie nieruchomo i zachowywać milczenie. Dlatego w regule przeznaczonej dla habitek dopuszczano możliwość selektywnego udziału w modlitwach zakonnych, przy zachowaniu codziennego uczestnictwa we Mszy św., odmawiania pacierza i rachunku sumienia.

Nad przestrzeganiem reguły obowiązującej habitki czuwała mistrzyni, ona też odpowiadała za ich wychowanie. Mistrzyni miała obowiązek zaszczepić w ich sercach umiłowanie Boga i czynienie wszystkiego w imię Jego miłości. O właściwym ukształtowaniu charakteru dziewczynek świadczyła też miłość okazywana bliźnim, szacunek, pokora i poszanowanie woli sióstr oraz osób starszych. O dojrzałości charakteru świadczyła umiejętność poskramiania zachcianek odnoszących się do jedzenia, picia i chęci posiadania. Dlatego powinnością mistrzyni był stały nadzór nad właściwym ukształtowaniem tej

\footnotetext{
15 AWiWa, sygn. B 8, s. 33, 50, 270; sygn. D 3.

16 AWiWa, sygn. A 14, s. 399.

17 Ibidem, s. 397-399.
} 
cechy osobowości, przyzwyczajenie dziewczynek do pytania o pozwolenie na konsumpcję czy użycie jakiegoś przedmiotu. Wiązało się to również z ćwiczeniem woli dziecka, co miało niebagatelne znaczenie w przyszłym życiu i rozwoju duchowości.

Habitki należało nauczyć właściwego zachowania się w różnych miejscach i sytuacjach. Przyzwyczajano je, że chór zakonny i refektarz to miejsca obowiązywania ciszy, a podczas odprawiania nabożeństw i modlitw obowiązuje całkowity zakaz rozmów. Gdyby jednak wyjątkowo zaistniała konieczność poinformowania o czymś, dopuszczano wypowiedzi szeptem, dlatego dzieci musiały umieć modulować głos, aby mówić jak najciszej. Skromność w zachowaniu, powolne przemieszczanie się, spuszczanie wzroku podczas pobytu w chórze i w trakcie rozmowy w furcie u kraty klasztornej było uznawane za właściwe i budujące dla tych, którzy przychodzili z dziewczynkami rozmawiać. Szczególną uwagę zwracano na ukształtowanie w nich prawdomówności i odwagi w przyznawaniu się do popełnionych czynów pokazując, że kłamstwo zawsze zostanie odkryte, a zachowanie takie jest sprzeczne $\mathrm{z}$ dobrym wychowaniem ${ }^{18}$.

Mała reguła stanowiła dla mistrzyni swoisty przewodnik do pracy z habitkami, które w przyszłości mogły, chociaż wcale nie musiały wstąpić do zakonu, a jej wierne przestrzeganie miało w przyszłości pomóc, aby za czasem i za laty [habitki - A. Sz.] stały się sposobnemi obserwować wielka Regułę za pomoca Boża, który je wiecznie ubłogosławi ${ }^{19}$.

Tak więc w klasztorze Wizytek wszystkie małe kandydatki do zakonu nie tylko mieszkały w społeczności sióstr zakonnych, oddzielone od pensjonarek i uczennic, ale wspólnie z zakonnicami uczestniczyły w nabożeństwach i razem z nimi spożywały posiłki. Czynnikiem określającym ich tożsamość i wpływającym na wytworzenie w podświadomości obrazu własnej osoby w przyszłości był również strój zakonny.

Jakie przesłanki mogły decydować w XVII w. o przeznaczeniu dziecka przez rodziców do zakonu? Motywy podjęcia takiej decyzji bywały różne. Niekiedy matka poświęcała jeszcze nienarodzone dziecko na służbę Bogu szczególnie, gdy podczas ciąży występowały komplikacje, a poprzednie porody kończyły się śmiercią dziecka lub, gdy umierały one wkrótce po narodzinach. I tak wypełniając śluby dziecko było w młodości oddawane do klasztoru, lub przez pewien czas nosiło strój zakonny w domu. Wierzono, że święci danego zakonu uchronią je przed nieszczęściami i chorobami oraz otoczą opieką. Tak było w przypadku córeczki Henrietty z Działyńskich Błędowskiej, która po śmierci kilkorga dzieci złożyła przyrzeczenie, że jej Michalinka będzie chodziła w habicie trynitarkim czy Franciszki Olimpii Conrade, najmłodszej córki medyka królowej Marysieński, która jako dziecko była ubierana w habit wizytki, a po uzyskaniu stosownego wieku wstąpiła do tego zakonu ${ }^{20}$. Z kolei Anna Karasińska, wojewodzina płocka, nie tylko złożyła ślub ofiarowania nienarodzonego dziecka do klasztoru, ale po przyjściu na świat sama karmiła piersią małą Eufrazję. Dziewczynka była wychowywana w domu ze świadomo-

\footnotetext{
18 Ibidem, s. 397-399.

19 Ibidem, s. 399.

${ }^{20}$ D. Żołądź-Strzelczyk, Dziecko $w$ dawnej Polsce, Poznań 2002, s. 162, 164-165; B. Fabiani, Życie codzienne na zamku królewskim w epoce Wazów, Warszawa 1996, s. 58
} 
ścią, że zostanie w przyszłości mniszką, co ją niezmiernie cieszyło, w końcu rodzice umieścili ją w Płocku u norbertanek i tam została zakonnicą ${ }^{21}$.

Zdarzały się też przypadki, gdy rodzice chcieli podziękować Bogu za pierworodne dziecko i wychowywali je z myślą o oddaniu do zakonu. Niekiedy za taką decyzją rodziców przemawiały względy czysto materialne, gdy wiadomo było, że zbytnie rozdzielenie majątku z powodu dużej liczby potomstwa, może spowodować znaczne zubożenie rodziny.

Przyczyną mogła być również niechęć rodziców do dziecka, niekiedy wręcz nienawiść lub próba pozbycia się córki niedołężnej, kalekiej, niemającej szans na ułożenie sobie życia w małżeństwie. W takim przypadku mogło chodzić o zabezpieczenie jej egzystencji na przyszłość lub po prostu o usunięcie dziecka z domu. A obdarowanie hojnym posagiem powodowało, że miejsce dla takiej panny można było znaleźć nie tylko w ubogich, ale i w zamożniejszych konwentach.

Tak więc wpływ na decyzję rodziców mogły mieć zarówno czynniki religijne, pobożność, zadośćuczynienie Bogu za okazane łaski, pozbycie się problemu, jak i względy typowo majątkowe. Nie zawsze jednak plany rodziców mogły być zrealizowane; o ile w przypadku małych dzieci mogli nawet wobec ich sprzeciwu umieścić je w klasztorze, o tyle nie mieli już takiej władzy wobec córek osiągających lata pozwalające na wstąpienie do zakonu. Prawo kościelne już od XVI w. zabraniało przyjmowania do zakonu dziewcząt, które same dobrowolnie nie wyraziły zgody na życie za klauzurą.

Wśród dziewczynek oddawanych do klasztoru Wizytek Warszawskich w pierwszym półwieczu istnienia konwentu udało się ustalić kilkanaście nazwisk habitek. Możliwe było to dzięki zapisom w księgach dochodów, gdzie obok informacji o opłatach wnoszonych przez pensjonarki umieszczono jako odrębną grupę - habitki. Wyjaśnić należy, że niekiedy ta sama dziewczynka najpierw wpisywana była jako habitka, później pensjonarka, a następnie jako kandydatka do zakonu i wreszcie nowicjuszka. Można to tłumaczyć dwojako - albo nieświadomym brakiem konsekwencji we wpisach, albo czynnikami związanymi ze zmianą statusu panienki. Jednak ze względu na dokładność, a nawet drobiazgowość zapisów w księgach dochodów i wydatków pierwsze z przypuszczeń wydaje się mniej prawdopodobne. Najpewniej dziewczynka w wieku kilku lat zostawała habitką, przebywała z zakonnicami i przygotowywała się do życia zakonnego, następnie w celu uzupełnienia wykształcenia, a możliwe że z powodu potrzeby zbadania stałości intencji, na pewien okres przenoszono ją na pensję i tutaj z pozostałymi uczennicami pobierała nauki. Następnie po przekonaniu się o stałości postanowień co do swojej przyszłości i prośbie o przyjęcie do nowicjatu odbywały się obłóczyny, po których już jako pełnoprawna kandydatka przebywała wśród nowicjuszek.

Bywały też sytuacje odwrotne, wcześniej pobyt na pensji, a dopiero potem przejście do tzw. habitku. Tak było w przypadku Agatki Wodzickiej, która najpierw oddana została do szkoły klasztornej prowadzonej przez wizytki. Wydaje się jednak, że pobożni rodzice już od samego początku mieli zamiar pozostawić ją w zakonie, jednak aby nie zniechęcić

${ }^{21}$ M. Borkowska, Życie codzienne..., s. 16; eadem, Leksykon zakonnic epoki przedrozbiorowej, t. 2, Warszawa 2005, s. 46. 
małego dziecka do życia klauzurowego, najpierw umieścili ją na pensji. Pensjonarką była przez cztery lata, pierwsza wpłata za jej pobyt odnotowana została w 1676 r., a pod koniec czerwca 1680 r. na życzenie rodziców dziewczynka została habitką22. Radość ich z tego powodu była niezmierna, a widok Agatki w stroju zakonnym napawał ich ogromnym szczęściem. Z tego powodu ufundowali dla wszystkich zakonnic w dniu święta Nawiedzenia, przypadającego na dzień 1 lipca, obiad, na który przekazali dwa duże półmiski kurcząt w potrawce oraz $d$ wa inne pieczonych kurcząt $i$ cielęciny, pasztet, torty 2, i 3 garnce wina oraz 24 chlebów białych ${ }^{23}$. Zobowiązali się również wpłacać corocznie na utrzymanie córki dość wysoką opłatę 400 złp, co odnotowane zostało w księdze przychodów w 1680 i 1681 r. $^{24}$ Jednak pomimo szczerych chęci rodziców dziewczynka nie wstąpiła do zakonu, prawdopodobnie w grudniu 1681 r. wysłana została wraz ze swoją dotychczasową mistrzynią, Katarzyną Teresą Tarłówną i innymi siostrami na nową fundację do Krakowa, nie ma jednak jej nazwiska wśród zakonnic profesji krakowskiej, nie ma też w spisach sióstr z innych klasztorów polskich z tego okresu ${ }^{25}$. Ale u wizytek krakowskich jest zapisana inna zakonnica o tym nazwisku Anna Konstancja, najpierw jako habitka, potem nowicjuszka w 1694 r. a od roku 1695 profeska. Wizytka ta była córką podczaszego warszawskiego Wawrzyńca, a siostrą Agaty Stanisławowej Tęgoborskiej, którą była zapewne wspomniana wyżej warszawska habitka Agatka. Na jej przykładzie można więc stwierdzić, że nie zawsze zamiary rodziców były zgodne z wolą córki, a ich marzenia ziściły się dopiero w przypadku kolejnej, młodszej córki oraz syna Michała, który jako jeden z czterech braci został duchownym i dostąpił godności kanonika ${ }^{26}$.

Podobnie przedstawiają się dzieje pobytu u wizytek warszawskich panienki o nazwisku Plaskowska (Pląskowska, Plaskosiu), za którą ojciec wnosił w latach 1678-1680 opłaty rozłożone na dwie raty roczne po 200 złp. Przy ostatnim wpisie znajduje się adnotacja, że należała do grona dawnych uczennic. Dziewczynką tą była zapewne córka Franciszka Pląskowskiego, pisarza skarbu koronnego. Ponownie w latach 1682-1684 w księgach rachunkowych można spotkać wzmianki o wpłatach na jej utrzymanie takiej samej wysokości jak poprzednio, ale przy nazwisku figuruje od tego czasu zawsze określenie de nostre petite Plaskosiu, co może sugerować o pobycie dziewczynki jako habitki ${ }^{27}$. Ponadto w 1682 r. ojciec jej obdarowywał siostry produktami spożywczymi, i tak w lutym 1682 r. przysłał 2 garnce wina i 6 karpi, na Wielkanoc przekazał 5 szczupaków, wyzinę, 2 chleby

22 AWiWa, sygn. B 8, s. 270, 291; sygn. D 3.

23 AWiWa, sygn. B 8, s.271.

24 Ibidem, s. 291; sygn. D 3.

25 M. Borkowska, Leksykon zakonnic epoki przedrozbiorowej, t. 1-3, Warszawa 2004-2008. W żadnym spisie nie odnalazłam zakonnicy o tym imieniu i nazwisku.

${ }^{26}$ Archiwum Wizytek Krakowskich (dalej AWiKr), rps Kronika klasztoru Nawiedzenia NMP w Krakowie 1681-1863, brak sygn., s. 190; AWiWa, sygn. B 8, s. 270; M. Borkowska, Leksykon..., t. 2, s. 316; K. Niesiecki, Herbarz Polski, t. IX, Warszawa 1979, s. 69-70. W 1685 r. Agata Wodzicka c. Wawrzyńca, skarbnika nurskiego zawarła małżeństwo ze Stanisławem Tęgoborskim, starostą małogoskim.

27 AWiWa, sygn. D 3; rps. Kronika klasztoru naszego warszawskiego 1682-1684, t. 4, sygn. B 9, s. 3, 83, 220, 228, 238, 253, 262, 277; B. Fabiani, Warszawska pensja..., s. 197-198. Franciszek Kazimierz Pląskowski h. Oksza wywodził się ze szlachty na Mazowszu i w Prusach, podczaszy trembowolski, pisarz skarbu koronnego (1678 r.). Zob. K. Niesiecki, Herbarz..., t. VII, Warszawa 1979, s. 319. 
szafranowe, 4 garnce wina i sarnę, a w lipcu tego samego roku 3 garnce wina i ser holenderski, chcąc okazać wizytkom swą wdzięczność ${ }^{28}$. Na nic zdały się starania zapobiegliwego rodzica, córka zapewne nie miała powołania i wystapiła z habitku, stąd brak jej nazwiska wśród zakonnic tego klasztoru ${ }^{29}$.

Habitką była też Basia Dunin, mała dziewczynka wymieniana jako siostrzenica ks. referendarza koronnego, Jana Małachowskiego, późniejszego biskupa krakowskiego, który w czasie jej pobytu w klasztorze był ojcem duchowym wizytek. Pierwsza opłata za pobyt Basi została wpisana w styczniu 1667 r., a sześciomiesięczny koszt jej utrzymania obliczony został na 150 złp, kolejne wpłaty napływały do listopada 1668 r., i jak się wydaje pokrywane były w zdecydowanej większości, a być może i wszystkie przez księdza Małachowskiego. Ona również nie wstąpiła do zakonu i nie figuruje w spisach żadnych innych konwentów w tym czasie ${ }^{30}$. Podobnie niewiele wiadomo o małej Annouche, pod tym imieniem zapisywana była prawdopodobnie mała Anna Oborska, za którą matka opłacała niewielką kwotę około 50 złp rocznie, płacone w ratach po połowie sumy. Dziewczynka należała więc do niezbyt zamożnej rodziny. Przebywała wśród habitek około trzech lat (1667-1669) i być może względy zdrowotne lub brak powołania spowodowały jej wystąpienie ${ }^{31}$. Plany rodziców co do przyszłości córki w zakonie miał też krajczy Wielkiego Księstwa Litewskiego - Tyszkiewicz; jego mała córeczka była u wizytek od 1680 r., a habitek nosiła od następnego roku. W 1682 r. krajczy wniósł za nią jednorazową opłatę w wysokości 600 złp. Nie wiemy, jakie były dalsze jej losy, nazwisko dziewczynki nie figuruje wśród profesek warszawskich ${ }^{32}$.

W grupie dziewczynek przeznaczonych do zakonu były też takie, które składały śluby i zostawały mniszkami. Losy ich były często zagmatwane, ponieważ najpierw miały pozostać na całe życie w zakonie, potem, gdy były w wieku umożliwiającym podjęcie ostatecznej decyzji rodzice lub opiekunowie starali się je odwieść od tego. Najtrudniejsze było dla dziewcząt to, że często wbrew własnej woli zgadzały się z postanowieniami rodziców, rozwijały w sobie powołanie a potem, wychowane od dziecka w klasztorze, nie potrafiły odnaleźć dla siebie miejsca poza murami klauzury i najczęściej, nawet po latach wracały do klasztoru.

Los taki był udziałem pierwszej z habitek warszawskich Marii Anny, nazywanej zdrobniale Marynią, córki Maksyma Cantarini - Włocha pochodzącego z Luki i Konstancji Bandinelli. Rodzice jej osiedleni byli w Polsce, a córka urodziła się w Krakowie. Ponieważ dziewczynka dość wcześnie została sierotą, opiekunowie postanowili umieścić ją u wizytek jako habitkę. Nie wiadomo, kto podjął powyższą decyzję, czy wuj niejaki Dą-

${ }^{28}$ AWiWa, sygn. B 9, s. 8, 13, 35.

${ }^{29}$ Ibidem, s. 83.

${ }^{30}$ AWiWa, rps Kronika klasztoru naszego warszawskiego, t. 2, syg. B 7, s. 315, B 8, s. 2, 7, 23; B. Fabiani, Warszawska pensja..., s. 194. W żadnych spisach zakonnic nie figuruje jej nazwisko. Zob. M. Borkowska, Leksykon..., t. 1,2,3.

${ }^{31}$ AWiWa, sygn. B 8, s. 14, 26, 37; sygn. D 3; B. Fabiani, Warszawska pensja..., s. 194. W księgach rachunkowych wpisywana była też Annouche w latach 1658-1659, była to nieznana bliżej Anusia przebywająca w szkole klasztornej na koszt królowej Ludwiki Marii. Por. B. Fabiani, Warszawska pensja..., s. 191-192.

32 AWiWa, sygn. B 9, s. 3; sygn. D 3; B. Fabiani, Warszawska pensja..., s. 198. 
browski, który mógł być jej ojcem chrzestnym, czy dziadek ze strony matki, który obok wuja figuruje w księgach rachunkowych jako osoba pokrywająca koszty jej pobytu. Faktem jest, że mała Maria Anna zamieszkała z wizytkami w klasztorze i od 1658 do 1663 r. była przygotowywana do wstąpienia do zakonu. Zresztą, jak można sądzić na podstawie spisanego po jej śmierci żywota, wizytki ją bardzo lubiły ze względu na stateczność i zadatki na dobrą zakonnicę. Nawet król Jan Kazimierz bywający w klasztorze, bardzo cenił sobie spacery po klauzurowym ogrodzie i rozmowy z nią na tematy religijne, uznając Marynię za pannę mądrą i dobrze rozgarniętą. Ale babka dziewczynki postanowiła, że najlepiej będzie dla wnuczki, gdy opuści klauzurę i zamieszka przy niej we Lwowie. Ponieważ wola starszej pani była ostateczna, Marysia pomimo wieku umożliwiającego jej podjęcie prawomocnej decyzji o wstąpieniu do zakonu opuściła klasztor i spełniła jej zamiar. Być może starsza pani nie kierowała się wyłącznie egoizmem, ale chciała sprawdzić stałość jej powołania przed podjęciem ostatecznej decyzji. Minęły kolejne trzy lata zanim dziewczynka powróciła za klauzurę, być może fakt ten miał miejsce po śmierci opiekunki lub po uznaniu przez nią, że powołanie wnuczki było prawdziwe, a szczęście znajdzie, wstępując do zakonu. I tak w 1669 r. Marysia została nowicjuszką, przyjmując imiona Maria Konstancja, dwa lata później złożyła śluby zakonne, a pełnione urzędy i funkcje potwierdzają, że w zakonie odnalazła swoje miejsce. W 1684 r. wysłana została na cztery lata do nowo powstałego klasztoru w Krakowie, gdzie znalazła się w grupie jego organizatorek, od 1694 wraz z innymi wizytkami organizowała klasztor w Wilnie, była też jego pierwszą przełożoną, a potem jeszcze czterokrotnie sprawowała tam najwyższy urząd. Siostra Cantarini jest przykładem dziecka, które będąc sierotą odnalazło swoje miejsce w zakonie ${ }^{33}$.

Sierotą nie była mała Teresa Kotowiczówna, nazywana przez zakonnice żartobliwie Teresią, córka kasztelana wileńskiego Andrzeja herbu Korczak, która znienawidzona przez matkę Barbarę Cecylię została oddana jako 6-letnia dziewczynka do klasztoru z zamysłem pozostawienia jej tam na zawsze ${ }^{34}$. Nie wiemy jaka była przyczyna niechęci matki do dziecka, które było posłuszne $i$ z ciała układności i obyczajów poważnych, estymacji miła i przyjemna panienka wszystkim" "35. Faktem było, że rodzicielka nosząc w sobie wrogość do córki nie inszą intencją w tym mając, tylko ażeby z oczu dziecięcia i z serca przyczyny odnawiania się nienawiści pozbywszy oddała ją do klasztoru, gdzie zaraz mały na nią habitek włożono ${ }^{36}$. Nie umieszczono jej na pensji, ale od razu wśród zakonnic, chcąc

${ }^{33}$ AWiWa, sygn. B 7, s. 31, 32, 77, 155, 177, 187; B 8, s. 30, 370; D 3; F. S. Ignaszewska, Historia fundacji klasztoru SS. Nawiedzenia NMP (Wizytek) w Krakowie (1681-1699), „Nasza Przeszłość” 58/1982, s. 12-13; M. Borkowska, Leksykon..., t. 2, s. 150; B. Fabiani, Warszawska pensja.., s. 191-192.

34 AWiWa, sygn. B 7, s. 314; M. Świątecka, Kotowiczówna Ludwika Teresa w: PSB, t. XIV, WrocławWarszawa-Kraków 1968-1969, s. 487; M. Borkowska, Leksykon..., t. 2, s. 151; K. Niesiecki, Herbarz..., t. V, s. 329. I lubo matka wielka niechęć miała przeciwko niej (jako się na[d]mieniło), przecież nie opuszczając nic z obligacyi macierzyńskiej, do wszelkiej ja zaczęła sposobić pobożności, awersją swoją od świata w niej awersją sprawując nie tylko sama źle ją traktując, lecz nadto jednej ochmistrzyni moc nad nia dając, która więcej sobie pozwalała ostrościa nad powolna wcale dziecina i skłonna do dobrego, aniżeli przystało. Zob.: S. Bross, M[atka] Franciszka Teresa Kotowiczówna. Wizytka warszawska, Opole 1949, s. 13.

35 S. Bross, M[atka] Franciszka..., s. 15.

36 Ibidem. 
przyzwyczaić dziecko do atmosfery życia klasztornego i rozbudzić powołanie zakonne. Jak wspomina kronikarka była czwartą z kolei habitką u wizytek, a pobyt swój rozpoczęła w lipcu 1667 r. i była przez trzy kolejne lata. Opłaty za nią regulowała matka, a wysokość rocznej należności została ustalona na $200 \mathrm{złp}^{37}$. Nie było żadnych problemów z pokryciem kosztów utrzymania, matka nic nie odmawiała, co do jej potrzeby należało, byleby tylko nie mówione byto, że dla Teresy, ale po prostu, że tego lub tamtego potrzeba. W przeciwnym razie wielce sie gniewem niezmiernym unosiła ${ }^{38}$.

Tereska była dzieckiem jak na swój wiek rozgarniętym, posłusznym i lubianym, a epizody z jej życia, zanotowane w pośmiertnym wspomnieniu, pozwalają ocenić cechy jej charakteru i osobowość. Od początku umieszczenia za klauzulą zakonnice bardzo ją polubiły, a zachowanie dziecka często doprowadzało je do rozbawienia. Ubrana w mały habit zakonny wyglądała dość pociesznie. Już w pierwszym dniu pobytu podczas wspólnego posiłku podano w refektarzu poziomki. Tereska siedziała przy stoliku przeznaczonym dla habitek i otrzymaną porcję owoców postanowiła posłodzić. Nie potrafiła jednak odróżnić soli od cukru, którego nie było na stole i doprawiła do smaku owoce solą. Kiedy zjadła pierwsze poziomki i zorientowała się w pomyłce, bez skrzywienia się chciała zjeść następne, nie ujawniając popełnionego błędu. Dopiero jedna z sióstr, obserwująca przez cały czas zachowanie dziewczynki, powiedziała o incydencie i Teresce przyniesiono nową porcję owoców. Fakt ten świadczy o ogromnym samozaparciu dziecka, które nawet po rozpoznaniu własnego błędu, być może z obawy przed konsekwencjami, nie przyznało się do jego popełnienia i starało się ponieść skutki własnych działań ${ }^{39}$.

Mistrzynią habitek w tym czasie była krótko siostra Maria Eleonora d Apchon de Ponsein, a po niej Katarzyna Krystyna Branicka, która dbała o właściwe ukształtowanie jej charakteru. Dziewczynka szybko dostosowała się do wymagań zawartych w dyrektorium dla habitek, zawsze posłuszna pytała o pozwolenie jedzenia, picia, opuszczenia swego miejsca przy stoliku, słuchała wszelkich wskazówek i nauk, ćwiczyła wolę i coraz bardziej utwierdzała się w przekonaniu o chęci bycia zakonnicą ${ }^{40}$. Przyzwyczajała się do rytmu życia zakonnego i na równi z siostrami brała udział w nabożeństwach i modlitwach. Chodziła z nimi do chóru i śpiewała Officium, nie mogła jednak zrozumieć, dlaczego nigdy nie wyznaczano jej na kierowanie zza pulpitu modlitwami wspólnotowymi. Pewnego razu postanowiła zrealizować marzenie, stanęła za pulpitem i przez krótki czas przewodziła modlitwom, jednak dość szybko zastąpiła ją jedna z zakonnic. Konsekwencją tego był rzęsisty płacz małej habitki, która doszła do wniosku, że nigdy nie została wyznaczona,

37 AWiWa, sygn. B 8, s. 119; sygn. D 3; M. Borkowska, Leksykon..., t. 2, s. 151.

38 S. Bross, M[atka] Franciszka..., s. 16.

39 Ibidem, s. 17; AWiWa, sygn. B 7, s. 314.

${ }^{40}$ Ćwiczyła się tedy $w$ cnocie wielkiej, submisyi, pobożności [...] Wszystkie nauki mistrzyń i cnot przykładów, bez trudności piękne figury albo wyobrażenia widzieć się dawaty wyrażone. Zob. S. Bross, M[atka] Franciszka..., s. 16. Nie miała żadna z tych dwóch Wielebnych Mistrzyń trudności z nią dla wielkiej powolności, dając z siebie ochotnie wyrobić, co tylko chciaty, intencje woli ich przenikając, także wyraźne rozkazanie gotowa była zawsze uprzedzić wykonaniem tego, co zrozumiewała, gdyby się nie byto zdawało bez rzetelnego rozkazania $w$ tym własna wolę uczynić. Im zaś podrastała $w$ lata, tym rozum perfekcja swoja większa brat, którym się do nauk akomodowała i co tylko Dyrektorium Habitek naznacza, ochotna aplikacya wykonywała. Zob. ibidem, s. 19. 
ponieważ siostry nazywają ją Teresią, a nie Teresą i poprosiła o używanie drugiej formy imienia, co spowodowało ogólne rozbawienie zakonnic ${ }^{41}$. Dziewczynka miała zadatki na dobrą zakonnicę, sam król Jan Kazimierz przepowiadał, że ta mądra i roztropna dziecina będzie nie tylko wizytką, ale i przełożoną konwentu ${ }^{42}$.

Chcąc utwierdzić się w przekonaniu o słuszności podjętej decyzji pozostania w zakonie Teresa wyjechała w listopadzie 1670 r. wraz z matką do domu rodzinnego w Wilnie. Pobyt dziewczynki w domu trwał niespełna pół roku, w marcu 1671 r. przybywający na obrady sejmu do Warszawy rodzice ponownie pozostawili naszą droga habitkę w klasztorze $^{43}$. W maju 1673 r. licząca 13 lat Teresa Kotowicz z małego habitku przeszła teraz do pensji z goracym pragnieniem zostania u nas w klasztorze zakonnica, gdy tylko dojdzie lat odpowiednich i otrzyma pozwolenie ${ }^{44}$. Rok później rozpoczęła postulat, a w 1675 r. została nowicjuszką, o co prosiła dobrowolnie bez przymusu i za pozwoleniem rodziców, wchodząc do grupy sióstr nowicjuszek chórowych i przyjmując imiona Franciszka Teresa ${ }^{45}$. Matka nowicjuszki oprócz posagu przekazała jako dar cenny kielich do kościoła oraz 100 liwrów na wystawny obiad z okazji obłóczyn ${ }^{46}$. Franciszka Teresa Kotowiczówna, podobnie jak wspomniana wcześniej Maria Konstancja Cantarini należały do grona najwybitniejszych postaci zakonu.

Teresa Kotowicz jest przykładem dziewczynki, która w klasztorze znalazła jako dziecko miłość, dobroć, zrozumienie i aprobatę. Dlatego zarówno Marysia Cantarini, jak i Teresa Kotowiczówna nie wyobrażały sobie życia poza klasztorem, a odpowiednio ukształtowane i pielęgnowane powołanie zakonne zaowocowało złożeniem ślubów zakonnych.

Wśród habitek znajdujemy też dzieci kalekie, dla których klasztor stanowić miał miejsce dalszej egzystencji. O takich dziewczynkach spotykamy w źródłach jedynie sporadyczne wzmianki. Przykładowo w 1665 r. wojewodzina lubelska Czartoryska urodziła dziewczynkę - karlicę, o jej istnieniu wiedziało tylko najbliższe otoczenie dziecka i być może ona również znalazła schronienie w jakimś klasztorze ${ }^{47}$. Reguła wizytek dopuszczała przyjmowanie do zakonu osób, które ze względu na słabe zdrowie czy defekty fizyczne nie mogły być przyjęte do innych konwentów, tutaj zaś mogły należeć do grupy sióstr stowarzyszonych, czyli mających prawa sióstr chórowych, ale bez obowiązku systematycznego uczestnictwa w modlitwach wspólnotowych. Dlatego też przyjmowano ułomne i kalekie dzieci jako kandydatki do zakonu ${ }^{48}$.

Jedną z nich była Klara Bielińska, zdrobniale nazywana Klarusią, pierworodna córka Franciszka herbu Junosza, miecznika koronnego, późniejszego wojewody malborskiego

${ }^{41}$ AWiWa, sygn. B 8, s. 9-10.

42 Ibidem, s. 68.

${ }^{43}$ Ibidem, s. 68, 68; S. Bross, M[atka] Franciszka..., s. 21-24.

44 AWiWa, sygn. B 8, s. 124.

45 Ibidem, s. 119; M. Borkowska, Leksykon..., t. 2, s. 151.

46 AWiWa, sygn. B 8, s. 119.

${ }^{47}$ B. Fabiani, Niziołkowie łokietki, karlikowie. Z dziejów karłów nadwornych w Europie, Warszawa 1980, s. 71 .

48 Por. Reguła Augustyna Świętego y Konstytucye dla Sióstr Zakonu Nawiedzenia, Warszawa 1691; S. Litak, Francuski nurt..., s. 142; idem, Z problemów edukacji..., s. 47-48. 
i jego żony Konstancji. Jako mała dziecina wypadła z kolebki przez niedozór swej mamki, co spowodowało uszkodzenie ciała ${ }^{49}$. Jak znaczne były uszkodzenia nie wiadomo, pewna jest zaś ich eskalacja z powodu niewłaściwego leczenia. Kuracja prowadzona przez różnych lekarzy polegała na unieruchomieniu dziecka przez założenie jej żelaznego gorsetu, który spowodował cofnięcie się żeber w kierunku kręgosłupa i uniemożliwił właściwy rozwój serca i płuc. Karusia była bardzo mała i niewiele rosła, ciało jej pozostało zdeformowane, rozwinęła się astma, a każdy wysiłek i znaczniejszy ruch powodował trudności oddechowe, prowadzące do duszności. Trudno z dzisiejszej perspektywy ocenić, w jakim stopniu sam upadek i stosowane leczenie, a na ile jakieś wrodzone schorzenia spowodowały zniekształcenie ciała. Wiadomo, że zrozpaczeni rodzice przeznaczyli ją do klasztoru, ale niemożliwe jest stwierdzenie, czy pobożna matka ofiarowała do zakonu swoje pierworodne dziecko przed wypadkiem, czy decyzja zrodziła się jako następstwo nieszczęścia, które spotkało Bielińskich. Ciotka dziewczynki, zakonnica w jednym z konwentów benedyktynek pragnęła, aby dziewczynkę oddać do zakonu św. Benedykta i być może nawet przygotowywano Karusię do tego, ponieważ są wzmianki, że chodziła w habicie benedyktyńskim. Nie wiemy tylko czy zakładano jej go w domu, czy mieszkała już w którymś z klasztorów. Ale ostatecznie rodzice zdecydowali się na umieszczenie jej wśród habitek u wizytek warszawskich, gdzie reguła zakonna była łagodniejsza, a być może wpływ na to miał fakt, że zakonnicą była tu jej krewna, młoda Katarzyna Helena Tarło, która zobowiązała się zająć ułomną kuzynką. Ówczesna przełożona wizytek Klaudia Agnieszka Camusar zgodziła się przyjąć dziewczynkę do grona habitek nie tyle z respektu dla zacności znakomitej rodziny, jak zapisano we wspomnieniu, ale aby zgodnie z przesłaniem św. Franciszka Salezego wypełnić jego wolę, który nakazywał przyjmować słabe i ułomne, byle miały zdrowego duch $a^{50}$. A tak właśnie oceniono po latach charakter dziewczynki, której duch żywy i odważny nie miat nic miękkiego rozczulającego się nad sobq ${ }^{51}$. Klara przybyła do klasztoru w listopadzie 1675 r. jako 10-dziewczynka, wraz z nią oddano na pensję jej rodzoną siostrę Teresę, nie wiemy jednak czy dziewczynki miały możliwość kontaktowania się ze sobą. Pozostawienie Klary w klasztorze prawdopodobnie spotkało się z oporem ze strony chorej dziewczynki, która mimo sktonności charakteru unoszącego ja do uporu i zaciętości potrafiła w sobie silnie zwalczać [te cechy - A. Sz.], że z czasem przy naszej usilnej pracy pierwsza przyznawała się do winy i prosita o odpuszczenie $e^{52}$. Wydaje się, że Klara powoli przyzwyczajała się do życia zakonnego, rozwijała w sobie powołanie, które rodziło się albo $\mathrm{z}$ wewnętrznego przekonania, albo z rezygnacji i uświadomienia sobie swojej sytuacji. Po niespełna 5-letnim pobycie jako habitka, Klara odbyła roczną próbę i w czerwcu 1680 r. została dopuszczona do nowicjatu, co świadczyło o stałości intencji i dobrowolności decyzji. Jednak stan jej zdrowia ulegał ciągłemu pogorszeniu, zwiększały się duszności i organizm był coraz mniej wydolny. Stąd decyzja mistrzyni o umieszczeniu jej w infirmerii i podjęciu leczenia. Doktor Conrade potwierdził jedynie

\footnotetext{
49 AWiWa, sygn. B 8, s. 177-178.

50 Ibidem, s. 178.

${ }^{51}$ Ibidem, s. 177-178.

52 Ibidem, s. 225.
} 
nieuleczalność choroby, rozwinęła się puchlina ze względu na znaczny ucisk żeber na serce i płuca a trudności z oddychaniem rokowały krótki żywot. Dlatego zaczęto przygotowywać ją do śmierci, która nastąpiła 2 listopada $1680 \mathrm{r}^{53}$

Drugą kaleką habitką w tym czasie była młodsza od Klary córka Konstancji z Branickich Bokumowej, siostrzenica Katarzyny Krystyny Branickiej - Anna Bokumówna. Ojciec dziewczynki, Jan Henryk herbu Paprzyca był stolnikiem Wielkiego Księstwa Litewskiego stale mieszkającym w Warszawie, a dziadek Jan Klemens Branicki pełnił urząd marszałka nadwornego ${ }^{54}$. Anna miała trzy siostry i czterech braci, z których jeden Jan Kazimierz został biskupem, a ją z racji zapewne kalectwa zdecydowano się oddać do klasztoru Wizytek, gdzie pod okiem ciotki Branickiej starano się rozbudzić w niej ducha zakonnego. Trafiła tu jako 5-letnia dziewczynka w 1678 r., weszła do grona habitek, gdzie przez pewien czas przebywała wspólnie z wspomnianą wyżej Klarą Bielińską. Na pensji była też jedna z jej sióstr, niestety nie wiadomo czy Konstancja (imienniczka matki), Urszula czy trzecia nieznana z imienia. Po prawie 10 latach życia w klauzurze i osiągnięciu wymaganego wieku w 1688 r. została nowicjuszką, a dwa lata później złożyła śluby profesji. Anna Konstancja, bo takie imiona przyjęła w zakonie żyła 48 lat, z czego w zakonie 32 lata $^{55}$.

Zdarzały się również przypadki, gdy habitki warszawskie były wysyłane na nowe fundacje, tam odbywały nowicjat i składały śluby profesji. I tak w $1681 \mathrm{r}$. wizytki warszawskie objęly ufundowany przez biskupa Jana Małachowskiego konwent krakowski. Profeską krakowską, która przygotowywała się do złożenia ślubów zakonnych w nowym klasztorze, była habitka warszawska Barbara Sapieżanka, córka Franciszka herbu Lis, koniuszego Wielkiego Księstwa Litewskiego i matki Anny z Lubomirskich ${ }^{56}$. Pierwszą wzmiankę o pobycie Basi u wizytek warszawskich zanotowano w 1681 r., była to pensja na jej utrzymanie w kwocie 200 złp, a zapis w księdze rachunkowej brzmiał za habitkę Basui koniuszankę. Kolejne należności wpływały regularnie aż do 1688 r., kiedy to dziewczynka osiągnęła wiek 15 lat i zapewne skierowana została do konwentu wizytek krakowskich, przeżywających trudności personalne. Tam właśnie w 1689 r. wstąpiła do nowicja-

\footnotetext{
${ }^{53}$ Klara Bielińska przyjęła imiona zakonne Maria Klara. M. Borkowska podaje, że zmarła w 1685 r., miałaby wtedy już 20 lat i możliwe byłoby uczynienie przez nią profesji, ponieważ do złożenia tych ślubów trzeba było mieć ukończone 16 lat. Jeśli warunek posiadania stosownego wieku był spełniony, to śluby można było złożyć nawet na łożu śmierci i taka okoliczność mogła zaistnieć w jej przypadku, ze względu na trwający przez kilka miesięcy pogarszający się jej stan zdrowia. Ponieważ zmarła jako nowicjuszka, należy domniemywać, że nie było podstaw prawnych do złożenia ślubów profesji, a więc zmarła nie w 1685, a w 1680 r. Por. AWiWa, sygn. B 8, s. 278-279; M. Borkowska, Leksykon..., t. 2, s. 151.

${ }^{54}$ B. Fabiani, Warszawska pensja..., s. s. 186, 197; K. Niesiecki, Herbarz..., t. II, s. 218-219. W Kronice (B 8) dziewczynka wpisana została pod imieniem Ignasia, natomiast w Księdze rachunkowej (D 3) podawane jest tylko nazwisko, ponadto wiadomo, że oprócz kalekiej dziewczynki na pensji przebywała w tym czasie jej rodzona siostra.

55 Obydwie siostry wyszły za mąż, Konstancja została żoną Hieronima Lubomirskiego, Urszula była żoną Jerzego Lubomirskiego, a po ponownym zamążpójściu została księżną witemberską, trzecia siostra to nieznana z imienia Karolowa Wapowska por. M. Borkowska, Leksykon..., t. 2, s. 152.

${ }^{56}$ K. Niesiecki, Herbarz..., t. VIII, s. 233.
} 
tu, przyjmując imiona Maria Barbara, po roku była już profeską, a miejscem jej pobytu do śmierci w 1702 r. był klasztor krakowski ${ }^{57}$.

Druga z Sapieżanek - habitek to wojewodzianka wileńska, córka Kazimierza Pawła Sapiehy i Krystyny z Chlebowiczów Sapieżyny, która przebywała w klasztorze warszawskim około 1682-1683 r. i za jej pobyt płacono rocznie 400 złp $^{58}$. Kasia nie została zakonnicą, rodzice wydali ją za mąż za wojewodę podlaskiego Stefana Mikołaja Branickiego ${ }^{59}$. To jej matce wizytki dedykowały tłumaczone z języka francuskiego i wydrukowane w 1682 r. dziełko Nowy Ray to jest rozmyślania na rekolekcye, będące publikacją przeznaczoną dla osób świeckich. Jakie motywy o tym zadecydowały nie wiadomo, bo jak wspomniano w kronice zgromadzenie zakonne miało wielu innych, znaczniejszych dobrodziei ${ }^{60}$.

Wychowaną w klasztorze warszawskim i posłaną na nową fundację do Wilna w 1694 r. była Eleonora Cecylia Masini (Mazynianka), córka Krzysztofa i Cecylii, licząca w 1682 r. około 9 lat i wtedy też po raz pierwszy w księgach rachunkowych odnajdujemy jej nazwisko. Nie należała do zbyt zamożnych dziewcząt, ponieważ rodzice wnosili za nią rocznie najniższą z uiszczanych w tym czasie opłat, tj. 200 złp. Jednak regularność w ich opłacaniu świadczy o sumienności rodziców, dziewczynka po sześciu latach pobytu wstąpiła do nowicjatu, a w 1689 r. była już profeską. Musiała być gorliwą zakonnicą, ponieważ znalazła się w grupie sióstr obsadzających nowy konwent w Wilnie ${ }^{61}$.

W ciągu dwóch ostatnich dziesięcioleci XVII w. coraz częstsze były praktyki umieszczania dziewcząt najpierw na pensji, a następnie przenoszenia ich z woli rodziców do grona habitek. Przeważnie w tym czasie było ich w ciągu roku od 2-3 do 5-6. Liczba ta była zgodna z instrukcjami rozsyłanymi między klasztorami, gdzie podawano, że dopuszcza się przyjmować od 2 do 4 habitek, ale na ziemiach polskich tu w tej stronie będa tedy mogty wziać 5 albo 6 najwięcej, a to dla jakiej znacznej i nadzwyczajnej okazyi ${ }^{62}$. Okazją tą mogła być chęć zapewnienia sobie nowych powołań na placówki w Krakowie i Wilnie.

Trzeba mieć świadomość, że liczna grupa dzieci przebywająca wśród zakonnic mogła zakłócać spokój klasztorny. Dlatego najkorzystniejsze było przyjmowanie ich $w$ dziesiatym lub dwunastym roku ile można, a jeżeliby się zdała stuszna przyczyna wziąć je w młodszych leciech, niech nie będa przynajmniej takich lat, aby nie były przyczyna turbacyi i przerwania pokoju klasztornego ${ }^{63}$. Okres 2-3 lat był wystarczający dla rozpoznania, czy dziewczynka posiada cechy charakteru i wolę zostania zakonnicą. Zresztą Katarzyna Kry-

57 AWiWa, sygn. D 3; sygn. B 9, s. 3, 83; AWiKr, Kronika..., s., 140; por. M. Borkowska, Leksykon..., t. 2 , s. 315 .

58 AWiWa, sygn. B 9, s. 3, 39

${ }^{59}$ K. Niesiecki, Herbarz..., t. VIII, s. 248,

${ }^{60}$ AWiWa, sygn. B 9, s. 37-38.

${ }^{61}$ Ibidem, s. 3; AWiWa, sygn.. D. 3; M. Borkowska, Leksykon..., t. 2, s. 152; K. Niesiecki, Herbarz..., t. VI, s. 339. Krzysztof Mazyni był sekretarzem i dworzaninem króla Jana Kazimierza.

${ }^{62}$ AWiWa, sygn. A 19.

63 Ibidem. 
styna Branicka słynęła z tego, że niezdatne kandydatki do zakonu usuwała bezwzględnie, stąd zapewne tak znaczna rotacja wśród habitek ${ }^{64}$.

Ponieważ o pozostałych dziewczynkach należących do grona habitek niewiele wiadomo, zestawienie ich nazwisk z lat 1658-1697 znajduje się w poniższej tabeli. Nie oznacza to, że wszystkie z nich zostały wprowadzone do wykazu, ponieważ niekiedy pojawiały się trudności z identyfikacją dziewczynek. Od ostatniego dziesięciolecia XVII stulecia zaprzestawano wpisów z adnotacją, czy wpłata dotyczyła pensjonarki czy habitki, a wszystkie dochody coraz częściej umieszczano razem. Zresztą w instrukcjach wyraźnie zalecano te zaś klasztory, które się będa mogły z tego wymówić, aby ich [habitek - A.Sz.] nie przyjmować, uczynia to bardzo dobrze ${ }^{65}$. Stąd występujące w różnych miejscach w tym czasie określenie mała przy nazwiskach dziewczynek mogło się odnosić do pensjonarek, wśród których zdarzały się także kilkuletnie dziewczynki.

Tabela. Zestawienie habitek w klasztorze Wizytek w Warszawie w latach 1658-1697

\begin{tabular}{|c|c|c|c|c|}
\hline Lp. & Imię i nazwisko & Imiona zakonne & $\begin{array}{c}\text { Odnotowana w źródłach } \\
\text { jako habitka w roku/ } \\
\text { latach }\end{array}$ & $\begin{array}{l}\text { Przybliżony } \\
\text { pobyt w latach }\end{array}$ \\
\hline 1. & Anna Maria Cantarini & Maria Konstancja & $1658-1663$ & 5 \\
\hline 2. & Barbara Dunin & & $1667-1668$ & 2 \\
\hline 3. & Annouche (Anna) Oborska & & $1667-1669$ & 3 \\
\hline 4. & Ludwika Teresa Kotowicz & Franciszka Teresa & $1667-1670$ & 4 \\
\hline 5. & Klara Bielińska & Maria Klara & $1675-1680$ & 5 \\
\hline 6. & Ignasia (Anna) Bokum (Bokumówna) & Anna Konstancja & $1678-1688$ & 10 \\
\hline 7. & Agatka Wodzicka & & $1680-1681$ & 2 \\
\hline 8. & Barbara Sapieżanka & Maria Barbara & $1681-1688$ & 7 \\
\hline 9. & [?] Tyszkiewiczówna (krajczanka) & & $1681-1682$ & 2 \\
\hline 10. & $\begin{array}{l}\text { mała Plaskowska (Pląskowska, } \\
\text { Plaskosiu) }\end{array}$ & & $1682-1684$ & 2 \\
\hline 11. & [?] Sapieżanka (wojewodzianka) & & $1682-1683$ & 2 \\
\hline 12. & $\begin{array}{l}\text { Eleonora Cecylia Masini } \\
\text { (Mazynianka) }\end{array}$ & Eleonora Cecylia & $1682-1686$ & 5 \\
\hline 13. & Skoroicka? [Skoraicka?] & & 1684 & 1 \\
\hline 14. & Gąszewska & & $1685-1688$ & 3 \\
\hline 15. & Rokworowska & & $1685-1688$ & 3 \\
\hline 16. & Leszczeńska [Leszczynska?] & & $1685-1687$ & 2 \\
\hline 17. & Sardie [Sardy] & & $1687-1694$ & 7 \\
\hline 18. & Suyska [Szujska?] & & $1688-1690$ & 3 \\
\hline
\end{tabular}

${ }^{64}$ M. Borkowska, Leksykon..., t. 2, s. 149.

${ }^{65}$ AWiWa, A 19. 


\begin{tabular}{|c|l|l|c|c|}
\hline 19. & Wołoszka [?] & & 1690 & 1 \\
\hline 20. & Nisucka [Niszczycka?] & & $1692-1693$ & 2 \\
\hline 21. & Giełgatówna & & 1692 & 1 \\
\hline 22. & Baptyścianka & & $1694-1697$ & 4 \\
\hline 23. & Franciszka Loupia [Lupi?] & Joanna Franciszka & $1694-1696$ & 3 \\
\hline
\end{tabular}

Źródło: AWiWa, sygn. B 7, sygn. B 8, sygn. B 9, sygn. D 3; M. Borkowska, Leksykon..., t. 2, s. 149-152.

Wszystkie odnotowane dziewczynki stanowią grupę 23-osobową, tylko 7 z nich zostało mniszkami. Świadczy to o znacznej selekcji wśród kandydatek, które albo same rezygnowały, albo nie uzyskiwały aprobaty zakonnic i zgody władz kościelnych z powodu niesprostania stawianym im wymaganiom.

Długość pobytu habitek w klasztorze była zróżnicowana i wynosiła 10 lat w przypadku ułomnej Bokumówny, około 7 lat Basi Sapieżanki i niejakiej panny Sardy, po 5 lat spędziły Marynia Cantarini, Klara Bielińska, Eleonora Cecylia Masini, a po 4 lata Ludwika Teresa Kotowicz i niejaka Baptyścianka. Pozostałe dziewczęta były w tzw. habitku przez 3 i mniej lat. Można wysnuć wniosek, że większość z występujących już po roku czy dwóch traciła bezpowrotnie złudzenia, co do chęci pozostania w klasztorze, a zostawały te, które miały autentyczne powołanie zakonne.

Warto jeszcze wspomnieć o wieku przyjmowanych habitek, najmłodszą odnotowaną była 5-letnia Ignasia Bokumówna oraz o rok starsza Tereska Kotowiczówna. Pozostałe były nieco starsze, a część z nich, przechodząca z pensji do habitku miała ponad 10-12 lat.

Opłaty roczne wpłacane za pobyt habitek były zróżnicowane i wynosiły od 200 do maksymalnie 400 złp. rocznie, wielkość ich zależała od stanu zamożności i deklaracji składanej przez rodziców. Były one zbliżone do kosztów pobytu na pensji.

Reasumując należy stwierdzić, że przyjmowanie dziewczynek jako kandydatek do zakonu nie spowodowało wykwitu powołań, a dawało jedynie wcześniejszą możliwość ich poznania, określenia czy nadaje się do życia zakonnego i w przypadku pozytywnej decyzji umożliwiało już od najmłodszych lat wychowanie zgodnie z zasadami reguły zakonnej.

\section{Our most beloved little sisters... or habitki in the convent of Warsaw-based Order of the Visitation of Holy Mary in the seventeenth century}

\section{Summary}

The sisters of the Order of the Visitation of Holy Mary, more commonly known as Visitationists, were brought to Poland from France by Marie Louise Gonzaga (known in Poland as Ludwika Maria) in 1654. Visitationists ran a boarding school for girls and provided education for inner-city girls from less well-to-do backgrounds. In addition, the religious order for women accommodated a novitiate for young girls admitted to this religious order for women - the so-called habitki (from the habit of a member under vows), i.e. candidates for the convent. The present article provides the 
reader with some detailed information on the mentioned group of candidates in relation the period covering the years from the establishment of the convent to the end of the seventeenth century. Habitki's cells were located in the part of the convent that also accommodated nuns, wore habits and participated in regular religious services and prayers with nuns. As a rule, they were usually minors up to girls of several years of age or older. They were supervised by a master-nun, appointed by Mother Superior, who took care of them, while a special rule of conduct determined their duties and responsibilities in the convent.

The reasons behind a decision to send little girls to the nunnery varied. At times, still unborn babies were sacrificed to God even before delivery, a custom to be found in particular within families where children were long in coming or where successive deliveries were death experiences for parents. Girls in the convent usually had both parents, but oftentimes they were orphans, disabled, hated by their parents or came from large families. By sending a daughter to a convent parents believed that her future was somehow secured. Occasionally, by doing so they simply got rid of a crippled child that often required extra care, or cleared the situation in prospective property settlement agreements in the family. More often than not, the plans conceived by parents, or foster parents, were not in line with intentions or expectations of girls.

A decision to stay within the confinement of the convent, however, was up to a candidate, who, after reaching the age of 15 , was entitled to seek for admittance to the full novitiate and, at the age of 16, could take simple vows. Between 1658 and 1697, the Warsaw-based convent had 23 habitki. Only 7 of them took vows.

At the time, no other religious order and convent had such a specific rule for child 